\title{
Bioedusiana
}

http://jurnal.unsil.ac.id/index.php/bioed

DOI: https://doi.org/10.37058/bioed.v5i2.2337

Bioedusiana

\section{Studi Anthophyta di Kota Magelang sebagai Sumber Pembelajaran Saintifik pada Perkuliahan Biosistematika Tumbuhan}

\section{Study of Anthophyta in Magelang City as Scientific Learning Resources for Plant Biosistematics Courses}

\author{
Muhammad Radian Nur Alamsyah ${ }^{1 *}$, Sekar Jati Pamungkas ${ }^{2}$, Andari Rosiana Meganingrum ${ }^{3}$, \\ Luthfiana Sabila Nur' afifah ${ }^{4}$
}

1,2,3,4 Program Studi Pendidikan Biologi FKIP Universitas Tidar, Jl. Kapten Suparman 39 Potrobangsan, Kota Magelang, 56116

\begin{abstract}
Abstrak
Kota "sejuta bunga" Magelang memiliki potensi keanekaragaman tumbuhan antophyta. Namun, potensi tersebut belum dianalisis lebih lanjut dan diotimalkan sebagai sumber belajar dalam pembelajaran saintifik Biosistematika Tumbuhan. Oleh karena itu, penelitian ini bertujuan untuk mengidentifikasi dan mengklasifikasi tumbuhan antophyta di Kota Magelang, dan menganalisis kelayakan potensinya sebagai sumber belajar dalam pembelajaran saintifik Biosistematika Tumbuhan. Penelitian ini menggunakan metode deskriptif analitik. Identifikasi antophyta dilakukan dengan metode perbandingan gambar dan lanjutkan proses klasifikasi secara hierarkis. Sampel diambil dari setiap populasi tumbuhan yang memiliki persamaan perawakan dengan area observasi sepanjang $800 \mathrm{~m}$ di Taman Tanggul Kali Kota. Analisis kelayakan potensi sumber belajar dilakukan melalui expert judgement dengan instrumen angket skala Likert. Penelitian ini berhasil mengidentifikasi 35 spesies tumbuhan antophyta di Kota Magelang dan dapat diklasifikasikan menjadi 32 genus, 25 familia, 16 ordo, dan 2 classis. Hasil analisis kelayakan sumber belajar memperoleh kategori baik $(83,85 \%)$, sehingga potensi tersebut layak menjadi sumber belajar dalam kegiatan pembelajaran saintifik pada mata kuliah Biosistematika Tumbuhan.
\end{abstract}

Kata kunci: Antophyta; Magelang; Sumber belajar; Pembelajaran Saintifik; Biosistematika Tumbuhan

\begin{abstract}
The city of "a million flowers" Magelang has the potential for diversity of antophyta plants. However, this potential has not been analyzed further and optimized as a learning resource in scientific learning of Plant Biosystematics. Therefore, this study aims to identify and classify antophyta plants in Magelang City, and to analyze their potential feasibility as a learning resource in Plant Biosystematics scientific learning. This research uses descriptive analytic method. Antophyta identification was carried out using the image comparison method and followed by the hierarchical classification process. Samples were taken from each plant population that has similar stature with an observation area of $800 \mathrm{~m}$ in the Kali Kota Tanggul Park. The feasibility analysis of potential learning resources was carried out through expert judgment with a Likert scale questionnaire instrument. This research succeeded in identifying 35 species of antophyta plants in Magelang City and can be classified into 32 genera, 25 families, 16 orders, and 2 classes. The results of the learning resources feasibility analysis obtained a good category (83.85\%), so that this potential is worthy to be a learning resource in scientific learning activities of the Plant Biosystematics course.
\end{abstract}

Keywords: Antophyta; Magelang; Learning Resources; Scientific Learning; Plant Biosystematics

ArticleHistory

Received: November, $15^{\text {th }}$ 2020; Accepted: September, 28 ${ }^{\text {th }}$ 2020; Published: December, $31^{\text {st }} 2020$

CorrespondingAuthor*

Muhammad Radian Nur Alamsyah, Program Studi Pendidikan Biologi FKIP Universitas Tidar, E-mail: m.radian.na@untidar.ac.id 


\section{PENDAHULUAN}

Biosistematika Tumbuhan merupakan ilmu yang mengkaji persoalan keanekaragaman dan evoluasi tumbuhan. Biosistematika pada awalnya lebih dikenal sebagai bentuk taksonomi eksperimental yang mengkaji proses evolusi dalam populasi (Gradstein \& Stace, 1981; Valentine \& Love, 1958). Taksonomi sendiri dipahami sebagai ilmu yang mempelajari deskripsi, identifikasi, penamaan, perbandingan, dan klasifikasi makhluk hidup (Singh, 2016; VaneWright, 2013). Biosistematika juga dikaitkan dengan kajian Sistematika (Bhattacharyya, 2016), yaitu kajian yang fokus membahas pada hubungan kekerabatan antarmakhluk dengan tujuan untuk merekonstruksi filogeni (Simpson, 2010; Sutrisno, 2016). Dalam perkembanganya, kajian Taksonomi dan Sistematik melebur dan menjadi satu dalam Biosistematika (Braby \& Williams, 2016; Probert, 2010). Adapun secara umum pembahasan dalam Biosistematika Tumbuhan, berkaitan dengan deskripsi tumbuhan, identifikasi tumbuhan, tata nama tumbuhan, dan klasifikasi tumbuhan (Simpson, 2010).

Biosistematika Tumbuhan menjadi salah satu mata kuliah yang dipelajari di Perguruan Tinggi. Penguasaan keterampilan ilmiah atau saintifik dalam Biosistematika Tumbuhan sebagai taksonomi eksperimental menjadi penting dimiliki oleh setiap mahasiswa, agar di masa depan dapat turut berkontribusi mengembangkan bagan keilmuan Biosistematika melalui proses saintifik. Namun, permasalahan umum yang terjadi dalam pembelajaran sains, termasuk Biosistematika Tumbuhan adalah penggunaan desain pembelajaran yang kurang tepat. Menurut Idu et al., (2011) Pembelajaran Biosistematika Tumbuhan di Perguruan tinggi lebih menekankan pada hapalan teoritik, sehingga aspek keterampilan (termasuk keterampilan proses sains) pada mahasiswa menjadi kurang berkembang.

Proses pembelajaran Biosistematika Tumbuhan lebih tepat disajikan melalui pembelajaran saintifik. Menurut Sujarwanta, (2012) pembelajaran saintifik menekankan pada pemberian pengalaman mahasiswa melalui kegiatan observasi atau eksperimen, tidak hanya sekedar duduk dan mendengarkan penjelasan di kelas. Desain tersebut berakar dari teori belajar konstruktivisme. Konsep dasar konstruktivisme adalah mendorong mahasiswa membangun struktur pengetahuan secara mandiri (Nurrohman et al., 2015; Yuliati, 2017). Kegiatan belajar dalam konstruktivisme berisi proses pengonstruksian kognisi antara pengetahuan awal yang dimiliki mahasiswa dengan kegiatan yang dilakukan sehingga muncul pengetahuan baru (Gitakarma \& Tjahyanti, 2012; Sundawan, M, 2016). Melalui desain pembelajaran saintifik mahasiswa didorong untuk mengkonstruksi fakta/konsep/prinsip melalui tahap, observing, questioning, experimenting, associating, dan communicating, (Machin, 2014; Zubaidah, 2014). Implementasinya, dalam pembelajaran saintifik dosen bertindak sebagai fasilitator dengan menyediakan perangkat pendukung untuk menciptakan iklim kondusif. Desain tersebut pada 
akhirnya akan dapat mengasah keterampilan saintifik yang dimiliki oleh para mahasiswa jika diterapkan secara konsisten.

Akan tetapi, desain pembelajaran saintifik perlu didukung sumber belajar khusus untuk menunjang tercapainya kompetensi setiap langkah-langkah pembelajaranya. Karakteristik sumber belajarnya berisi fakta/konsep/prosedur yang belum terstruktur dan belum tersaji secara lengkap. Sebagaimana lingkungan pembelajaran konstruktivisme menurut Aldridge et al. (2000) bersifat tidak pasti dan menuntut keaktifan serta daya kritis mahasiswa. Sehingga, sumber belajar utama yang berisi materi yang telah tersusun rapi dan lengkap, seperti buju ajar dan sejenisnya bukan menjadi alternatif yang tepat dalam pembelajaran saintifik.

Sumber belajar yang tidak terstruktur merupakan karakteristik sumber belajar by utilization, sebaliknya sumber belajar by design, merupakan sumber belajar telah memiliki struktur materi jelas karena sengaja disusun (Jailani, 2017; Sitepu, 2017). Sumber belajar by utilization tidak didesain secara khusus untuk kegiatan pembelajaran, tetapi keberadaannya dapat dimanfaatkan untuk keperluan pembelajaran (Najmulmunir, 2010). Berkaitan dengan kajian Biosistematika Tumbuhan, sumber belajar by utilization dapat ditemukan di luar ruangan, seperti di hutan, kebun, taman, dan tempat-tempat lain yang ditemukan objek tumbuhumbuhan. Senadan dengan Wibowo (2016) bahwa kegiatan belajar yang menggunakan sumber belajar by utilization dilakukan dengan memanfaatkan lingkungan sekitar dengan pembelajaran luar ruangan. Pemanfaatan lingkungan sebagai sumber belajar memiliki nilai lebih khususnya dalam hal ketersediaan dan kemudahan mendapatkanya (Zulkarnain, 2009).

Salah satu potensi sumber belajar by utilization mata kuliah Biosistematika Tumbuhan dapat ditemukan di kota Magelang. Kota Magelang memiliki branding "kota sejuta bunga' (Peraturan Daerah Kota Magelang Nomor 11 Tahun 2014, n.d.). Branding tersebut terimplementasi dalam tata kota Magelang yang didominasi dengan landscape taman. Tamantaman dibangun diberbagai tempat umum dan di tepi sepanjang jalan raya kota. Salah satu taman di Kota Magelang adalah Taman Tanggul Kali Kota yang memiliki area sepanjang 800 meter, yang merupakan taman kota terluas. Taman tersebut berada di tepi Jalan Ahmad Yani, Kecamatan Magelang Utara. Di dalamnya ditanam beranekaragam tumbuhan antophyta, yang merupakan tumbuhan dengan karakteristik utama memiliki organ bunga sejati (Simpson, 2010).

Namun, sejauh ini proses identifikasi dan klasifikasi keanekaragaman tumbuhan antophyta di kota Magelang masih sangat minim dilakukan. Penelitian terakhir terbatas pada identifikasi vegetasi dengan perawakan semak dan herba, yang hanya dilakukan di area Gunung Tidar (Handayani \& Amanah, 2018; Handayani \& Findahati, 2018) Sedangkan identifikasi dan klasifikasi khususnya tumbuhan antophyta di area lain belum dilaksanakan.

Dengan demikian, berdasarkan latar belakang yang telah dikemukakan di atas perlu dilakukan suatu penelitian untuk mengidentifikasi dan mengklasifikasi tumbuhan antophyta di 
Kota Magelang. Hasil dari proses tersebut kemudian dianalisis kelayakanya sebagai sumber belajar dalam pembelajaran saintifik mata kuliah Biosistematika Tumbuhan. Hasil dari penelitian ini diharapkan dapat memberikan kontribusi positif dalam meningkatkan value potensi lokal kota Magelang dan memberikan alternatif sumber belajar yang dapat dimanfaatkan dalam pembelajaran di perguruan tinggi.

\section{METODE}

Penelitian ini secara keseluruhan menggunakan metode deskriptif analitik melalui 2 tahap. Tahap pertama dilakukan untuk mengidentifikasi dan mengklasifikasi Anthophyta, tahap kedua dilakukan untuk menganalisis kelayakan potensi antophyta di kota Magelang sebagai sumber belajar dalam pembelajaran saintifik mata kuliah Biosistematika Tumbuhan.

Lokasi identifikasi Antophyta berada di Taman Tanggul Kali Kota, Kota Magelang. Plot pengamatan dibentuk sepanjang lokasi dengan panjang 800 meter. Pengumpulan data Antophyta dilakukan secara observasi. Sampel Antophyta dipilih secara purposive sampling, dengan mengambil salah satu individu dari setiap kelompok tumbuhan yang memiliki satu perawakan yang sama. Identifikasi tumbuhan menggunakan metode perbandingan gambar, yaitu dengan membandingkan data lapangan terhadap literatur identifikasi tumbuhan. Hasil identifikasi kemudian diklasifikasi menggunakan pendekatan klasifikasi hierarkis (Singh, 2016).

Tahap analisis kelayakan sumber belajar menggunakan kriteria dari Djohar (dalam Suhardi, 2012). Terdapat 6 aspek yang digunakan, yaitu 1) kejelasan potensi, 2) kesesuaian dengan tujuan belajar, 3) kejelasan sasaran, 4) kejelasan informasi yang diungkap, 5) kejelasan pedoman eksplorasi, dan 6) kejelasan perolehan yang diharapkan. Teknik pengumpulan data kelayakan sumber belajar dilakukan melalui metode expert judgement, oleh 2 ahli sumber belajar Biosistematika Tumbuhan dengan menggunakan instrumen angket tanggapan skala Likert yang terdiri dari 4 pilihan tanggapan (sangat baik, baik, kurang baik, tidak baik). Teknik analisis data hasil pemberian angket diolah secara deskriptif dengan menggunakan prosedur pembagian skor menjadi 5 kategori dari Sukarjo (dalam Ibrahim \& Ishartiwi, 2017).

\section{HASIL DAN PEMBAHASAN}

Berdasarkan hasil observasi, ditemukan beranekaragamn tumbuhan antophyta yang berada di Taman Tanggul Kali Kota. Setelah proses identifikasi dilakukan, terdapat 35 spesies tumbuhan antophyta berbeda yang berada di lokasi tersebut. Daftar spesies yang telah teridentifikasi dapat dilihat pada Tabel 1. Masing-masing spesies antophyta tersebut memiliki karakteristik yang berbeda-beda dengan tolok ukur bentuk morfologis organ luarnya. Adapun karakteristik morfologis yang mudah diidentifikasi adalah organ daun dan batang, karena letaknya yang relatif mudah diamati (daripada akar) dan selalu tersedia sepanjang waktu. Dalam 
proses identifikasi tumbuhan, untuk memudahkan pencarian nama spesies yang ditemukan, peneliti menggunakan aplikasi android Google Lens. Aplikai tersebut menerapkan tekonologi artificial intelligence, yang mampu menganalisis suatu foto dan memberikan informasi yang relevan terkait foto tersebut (Yusuf, 2018). Pengambilan gambar tumbuhan dengan kamera android melalui aplikasi tersebut, dapat secara otomatis memunculkan hasil nama lokal atau nama ilmiahnya. Namun, penentuan nama ilmiah menggunakan aplikasi Google Lens terkadang tidak $100 \%$ akurat, sehingga dalam pelaksanaanya peneliti melakukan validasi dengan menggunakan sumber lain, seperti buku taksonomi dan situs internet yang kredibel.

Tabel 1. Klasifikasi Hierarkis Tumbuhan Antophyta di Kota Magelang

\begin{tabular}{|c|c|c|c|c|}
\hline Classis & Ordo & Familia & Genus & Spesies \\
\hline \multirow{26}{*}{ 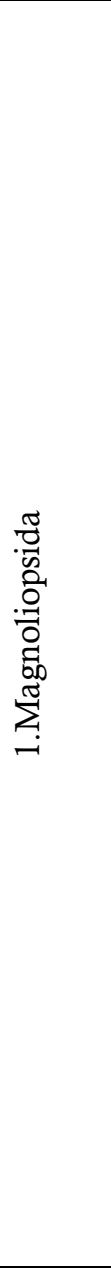 } & 1.Asterales & 1.Asteraceae & 1.Zinnia & 1.Z. angustifolia Kunth \\
\hline & \multirow[b]{2}{*}{ 2.Lamiales } & 2.Lamiaceae & 2.Coleus & 2.C. atropurpureus(L.) Benth \\
\hline & & 3.Verbenaceae & 3. Lantana & $\begin{array}{l}\text { 3.L. montevidensis (Spreng.) } \\
\text { Briq }\end{array}$ \\
\hline & \multirow{2}{*}{ 3.Myrtales } & 4.Lythraceae & 4. Cuphea & 4.C. aspera Chapm \\
\hline & & 5.Myrtaceae & 5. Syzygium & 5.S. paniculatum Gaertn. \\
\hline & \multirow{5}{*}{ 4.Gentianales } & \multirow{4}{*}{ 6.Apocynaceae } & 6. Erythrina & 6.E. orientalisL. \\
\hline & & & 7. Allamanda & 7.A. chatartica L. \\
\hline & & & \multirow{2}{*}{ 8. Plumeria } & 8.P. alba L. \\
\hline & & & & 9.P. pudica J acq \\
\hline & & 7.Rubiaceae & 9. Mussaenda & $\begin{array}{l}\text { 10.M. erythrophylla } \\
\text { Schumach. \& Thonn }\end{array}$ \\
\hline & 5.Violales & 8.Turneraceae & 10. Turnera & 11.T. subulata Sm. \\
\hline & \multirow{2}{*}{ 6.Euphorbiales } & \multirow{2}{*}{ 9.Euphorbiaceae } & 11. Euphorbia & 12.E. cyathophoraMurray \\
\hline & & & 12. Codiaeum & 13.C. variegatum $\mathrm{L}$. \\
\hline & \multirow{4}{*}{ 7.Caryophyllales } & \multirow{2}{*}{ 10.Portulacaceae } & \multirow{2}{*}{ 13. Portulaca } & 14.P. oleracea L. \\
\hline & & & & 15.P. grandiflora Hook \\
\hline & & 11.Amaranthaceae & 14. Alternanthera & $\begin{array}{l}\text { 16.A. dentata (Moench) } \\
\text { Stuchlik ex R.E. Fr }\end{array}$ \\
\hline & & 12.Nyctaginaceae & 15. Bougainvillea & 17.B. glabra Choisy \\
\hline & \multirow{2}{*}{ 8.Solonales } & \multirow{2}{*}{ 13.Convolvulaceae } & 16. Ipomoea & 18.I. sagittataPoir \\
\hline & & & 17. Evolvulus & 19.E. alsinoides (L.) L \\
\hline & 9.Rubiales & 14.Rubiaceae & 18. Ixora & 20.I. coccinea $\mathrm{L}$ \\
\hline & 10.Malvales & 15.Malvaceae & 19. Hibiscus & 21.H. rosa-sinensis L. \\
\hline & \multirow{3}{*}{ 11.Scrophulariales } & 16.Oleaceae & 20. Jasminum & 22.J. grandiflorumL. \\
\hline & & \multirow[b]{2}{*}{ 17.Acanthaceae } & 21. Ruellia & 23.R. tuberosa L. \\
\hline & & & 22. Asystasia & $\begin{array}{l}\text { 24.A. gangetica (L.) T. } \\
\text { Anderson }\end{array}$ \\
\hline & 12.Plumbaginales & 18.Plumbaginaceae & 23. Plumbago & 25.P. auriculata Lam. \\
\hline & 13.Apiales & 19.Araliaceae & 24. Schefflera & 26.S. grandiflora \\
\hline \multirow{9}{*}{ 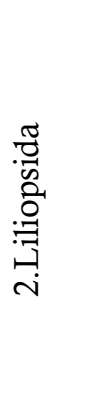 } & \multirow{3}{*}{ 14.Zingiberales } & 20.Heliconiaceae & 25. Heliconia & 27.H. psittacorum L. f. \\
\hline & & \multirow{2}{*}{ 21.Cannaceae } & \multirow{2}{*}{ 26. Canna } & 28.C. coccinea Mill \\
\hline & & & & 29.C. glauca L. \\
\hline & \multirow{5}{*}{ 15.Liliales } & \multirow{3}{*}{ 22.Agavaceae } & 27. Agave & 30.A. Americana L \\
\hline & & & 28. Furcraea & 31.F. foetida (L.) Haw \\
\hline & & & 29. Dracaena & 32.D. reflexa Lam. \\
\hline & & 23.Amaryllidaceae & 30. Zephyranthes & 33.Z. candida (Lind1.) Herb. \\
\hline & & 24.Iridaceae & 31. Neomarica & $\begin{array}{l}\text { 34.N. brachypus (Baker) } \\
\text { Sprague }\end{array}$ \\
\hline & 16.Commelinales & 25.Commelinaceae & 32. Tradescantia & 35.T. spathacea Sw. \\
\hline
\end{tabular}


Setalah proses identifikasi terhadap tumbuhan antophyta menghasilkan nama-nama spesies yang berbeda, langkah selanjutnya yaitu melakukan proses klasifikasi atau pengelompokkan. Klasifikasi dalam penelitian ini menggunakan klasifikasi hierarkis, dimana setiap tumbuhan dikelompokkan berdasarkan tingkatan taksonya dari rendah ke tinggi. Tabel di atas juga menampilkan hasil klasifikasi hierarkis dari seluruh spesies antophyta yang teridentifikasi. Berdasarkan data tersebut, seluruh spesies yang ada dapat dibagi menjadi 32 genus, 25 famili, 16 ordo, dan 2 kelas.

Pada Gambar 1 disajikan persentase jumlah spesies tiap tingkat takson ordo Anthophyta yang berhasil diidentifikasi di lokasi pengamatan. Melalui data terebut dapat diketahui mana ordo Anthophyta yang mendominasi, yang banyak ditemukan di lokasi pengamatan.

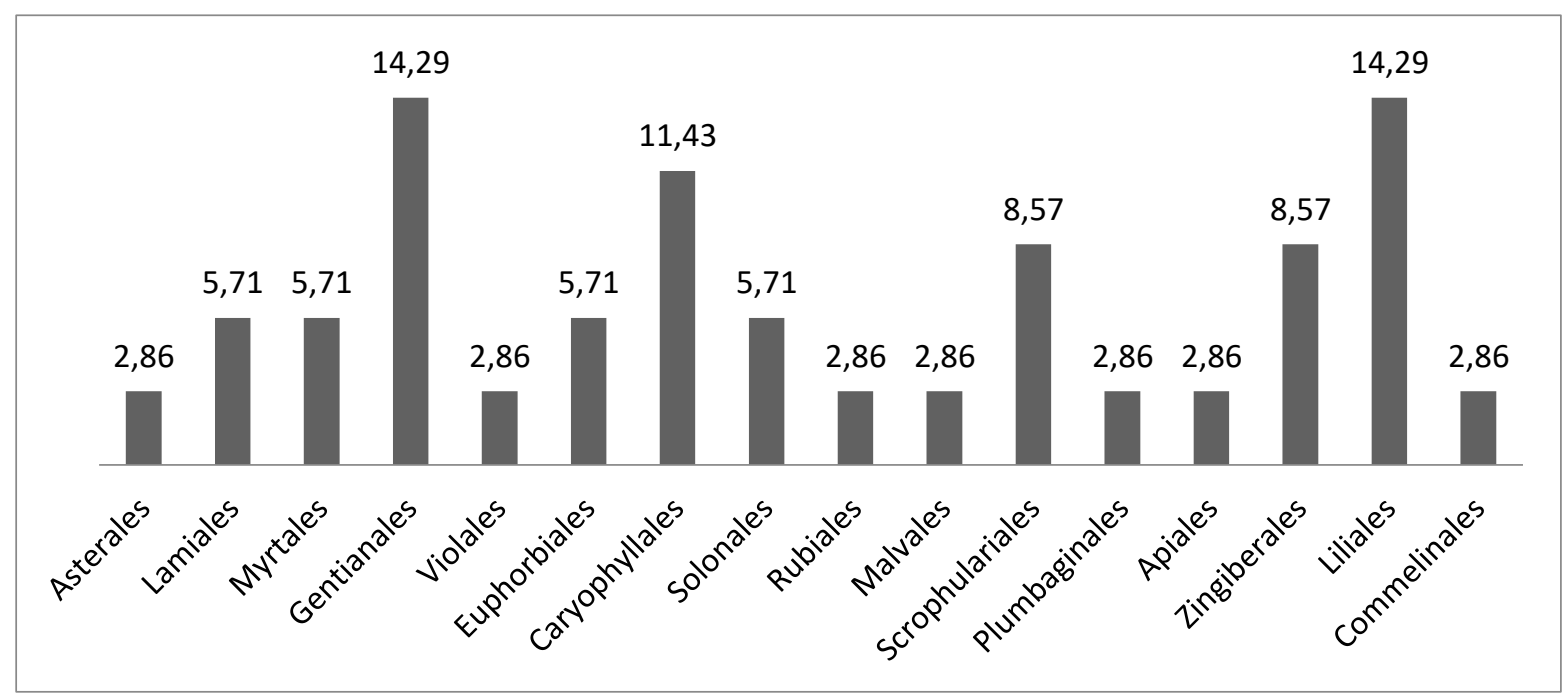

Gambar 1. Persentase (\%) Jumlah Spesies Antophyta Setiap Ordo

Penentuan ordo dominan adalah dengan menentukan ordo dengan persentase jumlah spesies $>10 \%$. Berdasarkan ketentuan tersebut, terdapat 3 ordo terbanyak, yaitu Gentinales (dengan persentase jumlah spesies 14,29\%), Liliales (dengan persentase jumlah spesies 14,29\%), dan Caryophyllales (dengan persentase jumlah spesies 11,43\%). Beberapa Tabel 2, 3, dan 4 berikut disajikan deskripsi gambar dan karakteristik dari setiap spesies pada ordo dominan.

Tabe1 2. Karakteristik Spesies pada Ordo Gentianales di Taman Tanggul Kali Kota

\begin{tabular}{|c|c|c|}
\hline Spesies & Gambar & Karakteristik \\
\hline Allamanda chatartica L. & & $\begin{array}{l}\text { Habitus perdu; Batangnya: berkayu, } \\
\text { bulat, berbuku-buku, tiap buku terdapat } \\
\text { daun yang melingkar, bergetah, } \\
\text { percabangan monopodial; Daunnya: } \\
\text { tunggal, lonjong, tepi rata melipat ke } \\
\text { bawah, ujung dan pangkal meruncing, } \\
\text { pertulangan menyirip, hijau; Bunganya: } \\
\text { majemuk, bentuk tandan, kelamin 2, } \\
\text { kelopak bentuk lanset, kepala putik } \\
\text { bercangap 2, mahkota bentuk terompet; }\end{array}$ \\
\hline
\end{tabular}




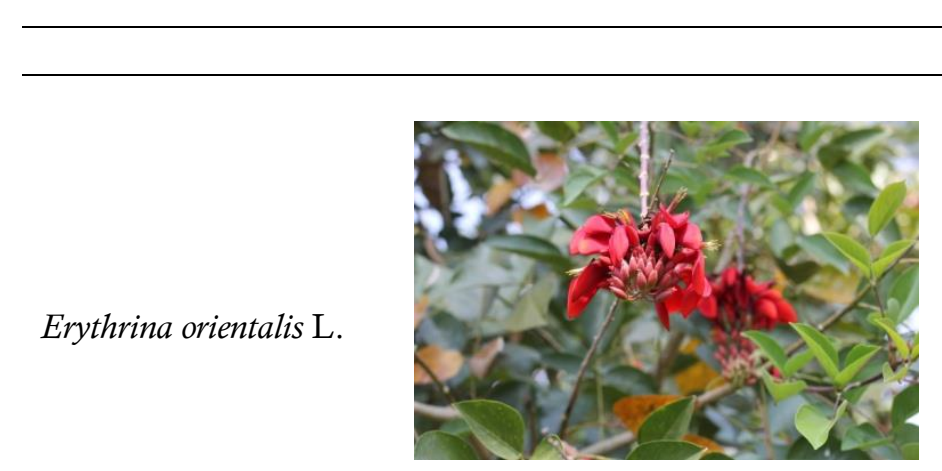

Akarnya tunggang. Perawakannya pohon; Batangnya:
berkayu, berbentuk silinder, tangkai daun silinder, berduri; Daunnya: trifoliate (daun majemuk dengan 3 anak daun), berbentuk bulat telur terbalik, segitiga atau belah ketupat dengan ujung tumpul, pertulangan daun menyirip; Bunganya: tersusun dalam tandan (racemus), bunga lengkap, asimetris, bentuk mahkota seperti sabit; Buahnya adalah buah polong.

Perawakannya perdu; Akarnya tunggang;

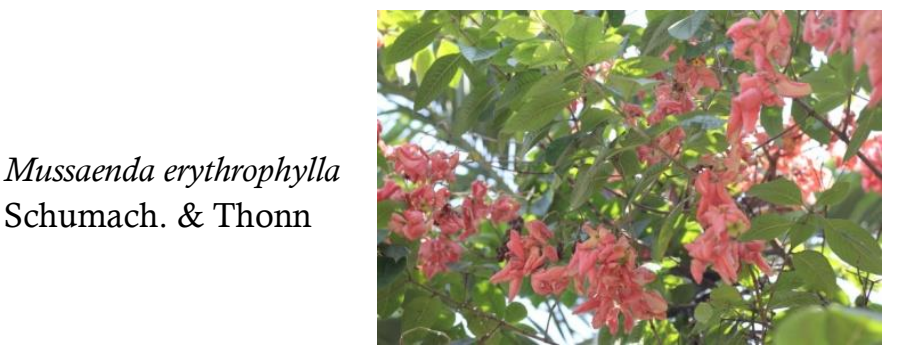

Batangnya: bulat, percabangan monopodial; Daunnya: tunggal, filotaksis berhadapan bersilang, berbentuk bulat telur runcing, pertulangan menyirip; Bunganya: lengkap, biseksual, bersimetri 1, bentuk kelopak bulat telur, warna kelopak merah muda, letak bakal buah tenggelam; Buahnya: buni, berbentuk bulat telur.

Perawakanya pohon; Daunya: tunggal berhadapan, lanset, ujung dan pangkalnya meruncing, berwarna hijau dan tebal, pertulangan nampak; Batangnya: bulat, berkayu keras, banyak percabangan, kulitnya bergetah. Bunganya: banci atau aktinomorf, mahkotanya 5 helai berwarna merah muda, Tangkai putik pendek dengan dasar bunga menonjol menutupi tabung kelopak.

Perawakannya perdu atau pohon kecil;

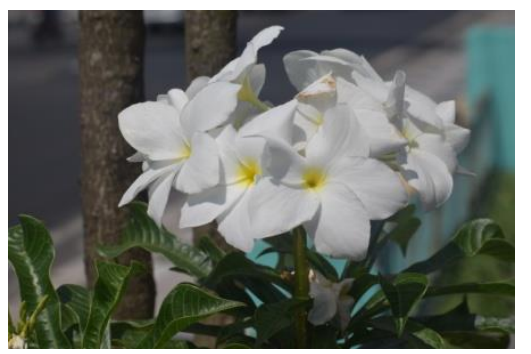
Batangnya: hijau kelabu, lateks putih seperti susu; Daunnya: tunggal, berseling, helaian membiola, pangkal menirus, tepi rata mengombak, bercuping 2 , ujung melancip, permukaan adaksial daun hijau tua, permukaan abaksial pucat; Bunganya: perbungaan terminal, gundung, daun kelopak berlekatan, daun mahkota berlekatan mencorong, mahkota berwarna putih; Bakal buah setengah tenggelam. 
Tabel 3. Karakteristik Spesies pada Ordo Liliales di Taman Tanggul Kali Kota

\begin{tabular}{|c|c|c|}
\hline Spesies & Gambar & Karakteristik \\
\hline Agave Americana L & & $\begin{array}{l}\text { Batangnya: tidak berbatang; Daunnya: } \\
\text { roset, betuk oval ujung lancip, tebal, } \\
\text { sedikit kaku, tepi daun diselimuti duri- } \\
\text { duri, daun berwarna kuning, hijau } \\
\text { muda, hijau tua, putih; Tanaman ini } \\
\text { memiliki nama lain lidah buaya } \\
\text { Amerika. }\end{array}$ \\
\hline Dracaena reflexa Lam & & $\begin{array}{l}\text { Perawakannya: tumbuh tegak; } \\
\text { Batangnya: bulat, beruas-ruas; } \\
\text { Daunnya tunggal, tidak bertangkai, } \\
\text { pelepah memeluk batang, pertulangan } \\
\text { daun sejajar, permukaan licin, } \\
\text { berwarna hijau bercampur putih. }\end{array}$ \\
\hline Furcraea foetida (L.) Haw & & $\begin{array}{l}\text { Perawakannya: semak kuat bentuk } \\
\text { tajuk V semu; Batangnya: roset basal, } \\
\text { memiliki selubung fibrosa kayu, } \\
\text { tangkai berbunga berkayu; Daunnya: } \\
\text { berwarna hijau atau kuning-hijau } \\
\text { bentuk linear-lanset, ujungnya runcing; } \\
\text { Bunganya: terminal banyak jumbai, } \\
\text { panjang 2,5-3,3 cm dengan } 1,0-1,8 \mathrm{~cm} \\
\text { lebar; Akarnya: lateral, halus }\end{array}$ \\
\hline $\begin{array}{l}\text { Neomarica brachypus } \\
\text { (Baker) Sprague }\end{array}$ & & $\begin{array}{l}\text { Perawakannya: herba; Daunnya: } \\
\text { sejajar, lanset, berwarna hijau muda } \\
\text { dan tua; Batangnya: rimpang sebagai } \\
\text { umbi memanjang; Bunganya: } \\
\text { berwarna kuning, sepal lebih besar } \\
\text { daripada tepal bagian dalam, tanda } \\
\text { coklat-ungu di dasarnya, benang sari } \\
\text { berfilamen bebas, bentuk memiliki } 2 \\
\text { lobus. }\end{array}$ \\
\hline $\begin{array}{l}\text { Zephyranthes candida } \\
\text { (Lindl.) Herb }\end{array}$ & & $\begin{array}{l}\text { Perawakannya: herba perenial; } \\
\text { Daunnya: pipih panjang berwarna } \\
\text { hijau tua mengkilap, tersebar secara } \\
\text { linear, helaian utuh; Bunganya: } \\
\text { terompet, mahkotanya } 2 \text { lingkaran, } \\
\text { aktinomorf atau zigomorf, benang sari } \\
\text { 6; Buahnya: buni; Bijinya: endosperm } \\
\text { dengan berdaging, lembaga pipih. }\end{array}$ \\
\hline
\end{tabular}


Tabel 4. Karakteristik Spesies pada Ordo Gentianales di Taman Tanggul Kali Kota

\begin{tabular}{|c|c|c|}
\hline Spesies & Gambar & Karakteristik \\
\hline $\begin{array}{l}\text { Alternanthera dentata } \\
\text { (Moench) Stuchlik ex } \\
\text { R.E. Fr }\end{array}$ & & $\begin{array}{l}\text { Perawakannya perdu atau semak yang } \\
\text { padat. Tanaman groundcover atau } \\
\text { penutup tanah jenis herba. Daunya: } \\
\text { berwarna ungu merah anggur, berdaun } \\
\text { tunggal, lunak, dengan ujung } \\
\text { meruncing. Bunganya: berukuran kecil, } \\
\text { muncul di ujung batang dan ketiak } \\
\text { daun. Bijinya: bulat, sangat kecil, dan } \\
\text { bayak. Batangnya: berwarna ungu, dan } \\
\text { kecil. Akarnya: tunggang, kuat dan } \\
\text { dalam. }\end{array}$ \\
\hline
\end{tabular}

Bougainvillea glabra
Choisy

Perawakannya perdu tegak. Daunnya: berwarna hijau, berbentuk bulat oval, bertepi daun merata, dan meyirip. Bunganya: majemuk, tidak lengkap, tumbuh di ketiak daun, kaku, dan keras. Batangnya: berwarna coklat, berkayu, bulat, dan berduri dengan percabangan monopodial. Akarnya: tunggang dengan bertumbuhan vertikal.

\begin{tabular}{|c|c|}
\hline $\begin{array}{l}\text { Portulaca grandiflora } \\
\text { Hook }\end{array}$ & $\begin{array}{l}\text { Perawakannya terna atau semak-semak } \\
\text { kecil. Daunnya: tunggal, tebal, } \\
\text { berdaging, dan spiral teratur. Bunganya: } \\
\text { berdiameter } 2-3 \mathrm{~cm} \text { dan berwarna-warni } \\
\text { dengan benang sari yang mencolok. } \\
\text { Bijinya: berwarna coklat kehitaman dan } \\
\text { berbentuk bulat. Batangnya: berwarna } \\
\text { coklat keunguan dan berbetuk bulat. } \\
\text { Tanaman ini memiliki nama lain krokot } \\
\text { mawar atau sutra bombay. }\end{array}$ \\
\hline Portulaca oleracea L. & $\begin{array}{l}\text { Perawakannya terna atau semak-semak } \\
\text { kecil. Daunya: tunggal, berwarna hijau, } \\
\text { tebal berdaging, dan berbentuk bulat } \\
\text { telur dengan tepi rata. Bunganya: } \\
\text { majemuk, tumbuh di ujung cabang, } \\
\text { kecil, berkepala putik tiga, bertaju dan } \\
\text { bersayap berkelopak merah, kuning, } \\
\text { hijau. Bijinya: hitam, bulat, dan } \\
\text { mengkilap. Batangnya: bulat, berwarna } \\
\text { merah keunguan dan tebal. Akarnya: } \\
\text { tunggang dan berwarna putih. }\end{array}$ \\
\hline
\end{tabular}

Data potensi sumber belajar antophyta dari hasil proses identifikasi dan klasifikasi antophyta di Taman Tanggul Kali Kota yang telah diperoleh sebelumnya, kemudian dianalisis kelayakanya sebagai sumber belajar. Sumber belajar tersebut diperuntukkan dalam kegiatan pembelajaran saintifik mata kuliah Biosistematika Tumbuhan. Pengintegrasian tumbuhan lokal sebagai sumber belajar, selain sebagai suatu bentuk inovasi pembelajaran juga dapat 
menyumbang dalam upaya konservasi tumbuhan (Primack, 2013). Hasil tinjauan ahli terhadap kelayakan sumber belajar yang diangkat tersaji dalam Tabel 5 dan Tabel 6. Secara keseluruhan (mean) hasil analisis kelayakan potensi sumber belajar memperoleh persentase 83,85 dengan kategori baik (artinya layak digunakan). Hal itu sesuai dengan hasil penelitian yang diperoleh Mumpuni (2013) yang menyimpulkan bahwa tumbuhan lokal (berada di daerah tertentu) dapat berpotensi sebagai sumber belajar di perguruan tinggi pada mata kuliah biologi.

Tabel 5. Kategori Aspek Pengangkatan Sumber Belajar

\begin{tabular}{clcc}
\hline No. & \multicolumn{1}{c}{ Aspek } & Persentase (\%) & Kategori \\
\hline 1. & Kejelasan potensi & 84,38 & Baik \\
\hline 2. & Kesesuaian dengan tujuan belajar & 87,50 & Baik \\
\hline 3. & Kejelasan sasaran & 87,50 & Sangat Baik \\
\hline 4. & Kejelasan informasi yang diungkap & 78,13 & Baik \\
\hline 5. & Kejelasan pedoman eksplorasi & 83,33 & Baik \\
\hline 6. & Kejelasan perolehan yang diharapkan & 79,17 & Baik \\
\hline \multicolumn{2}{c}{ Mean } & 83,85 & Baik \\
\hline
\end{tabular}

Tabel 6. Kategori Kesesuaian Potensi Sumber Belajar Antophyta dengan CPMK

\begin{tabular}{clcc}
\hline No. & \multicolumn{1}{c}{ CPMK } & $\begin{array}{r}\text { Mean Skor } \\
\text { Kesesuaian }\end{array}$ & Kategori \\
\hline 1 & Menjelaskan ruang lingkup dan prinsip Biosistematika Tumbuhan & 3,5 & Baik \\
\hline 2 & Menjelaskan berbagai sumber data Biosistematika Tumbuhan & 3,5 & Baik \\
\hline 3 & Menjelaskan konsep dan prinsip tata nama tumbuhan & 3,5 & Baik \\
\hline 4 & Menjelaskan konsep dan tata cara identifikasi tumbuhan & 3,5 & Baik \\
\hline 5 & Menjelaskan sejarah dan prinsip klasifikasi dan filogeni tumbuhan & 3,5 & Baik \\
\hline 6 & Menjelaskan asal usul dan keanekaragaman Antophyta & 3,5 & Baik \\
\hline 7 & Menerapkan prosedur saintifik & 3,5 & Baik \\
\hline
\end{tabular}

\section{Karakteristik Spesies pada Ordo Gentianales di Kota Magelang}

Gentianales merupakan salah satu ordo dengan spesies terbanyak yang telah teridentifikasi. Terdapat 5 spesises yang termasuk ordo Gentianales yang ditemukan dengan karakteristik berbeda-beda. Karakteristik pada ordo Gentianales yang ditemukan di Taman Tanggul Kali Kota Magelang menunjukkan kesesuaian dengan karakteristik ordo Gentianales pada umumnya (Tabel 2). Tumbuhan yang tergolong dalam ordo Gentianales merupakan tumbuhan terna, semak, atau pohon. Kebanyakan daun dari ordo ini merupakan daun tunggal berhadapan atau berkarang. Tumbuhan yang tergolong dalam ordo Gentianales memiliki karakteristik daun yang berhadapan, daun tunggal atau majemuk menyirip, tidak memiliki floem internal (Bhattacharyya, 2016). Jenis kelamin bunga tumbuhan ini adalah banci, jarang sekali tumbuhan ordo ini berkelamin tunggal. Bunganya aktinomorf, berbilangan 4 hingga 5, daun mahkota saling berlekatan dengan bagian kuncup bunganya memuntir ke satu arah. Jumlah benang sari sama dengan jumlah taju mahkota, dengan letak yang saling berselang seling. 


\section{Karakteristik Spesies pada Ordo Liliales di Kota Magelang}

Jumlah spesies ordo Liliales yang teridentifikasi sama dengan jumlah spesies pada ordo Gentianales, yaitu 5 spesies. Kelima spesies tersebut memiliki kemiripan ditinjau dari perawakan morfologinya (Table 3). Karakteristik pada ordo Liliales yang ditemukan di Taman Tanggul Kali Kota Magelang menunjukkan kesesuaian dengan karakteristik ordo Liliales pada umumnya. Tumbuhan dari ordo Liliales memiliki habitus berupa herba, jarang yang berupa tanaman berkayu atau perdu, ada sedikit yang berupa pohon bercabang dengan atau tanpa pertumbuhan sekunder. Batang terdapat di dalam tanah, kebanyakan bermodifikasi menjadi rimpang, atau umbi lapis. Daun umumnya tersebar, jarang berhadapan, atau dalam lingkaran, linear (daun pita) atau lanset, helaian daun utuh, jarang berupa daun majemuk, pertulangan daun umumnya sejajar, atau menjala pada beberapa tanaman (botani sistematik). Bunganya banci karena adanya reduksi salah satu alat kelaminnya menjadi berkelamin tunggal, aktinomorf atau zigomorf, biasanya tersusun dalam rangkaian yang bersifat rasemos. Buahnya berupa buah kendaga atau buah buni. Biji dengan endosperm berdaging atau seperti tanduk (Tjitrosoepomo, 2013).

\section{Karakteristik Spesies pada Ordo Caryophyllales di Kota Magelang}

Ordo Caryophyllales adalah ordo dengan spesies terbanyak ketiga setelah Gentianales dan Liliales. Terdapat empat spesies yang termasuk ordo Caryophyllales yang ditemukan di Taman Tanggul Kali Kota dengan perawakan yang khas (Tabel 4). Menurut Tjitrosoepomo (2013) ordo Caryophyllales memiliki habitus berupa herba, terna, perdu, pohon, atau tanaman merambat. Rata-ratra berdaun tunggal dan tidak mempunyai daun penumpu. Bunganya banci atau berkelamin tunggal, bertenda tunggal atau rangkap jelas dengan kelopak bunga, dan aktinomorf karena adanya reduksi. Benang sari dalam satu lingkaran, dua lingkaran atau berhadapan dengan tenda bunga. Bakal buah menumpang atau tenggelam, umumnya beruang satu.

\section{Kelayakan Sumber Belajar Berdasarkan Aspek Kejelasan Potensi}

Aspek kejelasan potensi ditentukan oleh keberadaan subjek dan permasalahan yang dapat diungkap (Suratsih et al., 2009). Subjek dalam hal ini adalah tumbuhan antophyta. Adapun permasalahan yang dapat diungkap melalui subjek tersebut adalah tentang keanekaragaman antophyta, yang merupakan objek kajian Biosistematika Tumbuhan. Aspek kejelasan potensi memperoleh presentase $84.38 \%$ dengan kriteria baik. Nurrohman et al., (2015) mengatakan jika setiap subjek dan objek apapun dan dimanapun dapat memberikan pengalaman belajar, maka dapat berpotensi menjadi sumber belajar. 


\section{Kelayakan Sumber Belajar Berdasarkan Aspek Kesesuaian Dengan Tujuan Belajar}

Aspek ini berkaitan dengan relevansi antara subjek dan permasalahan di lapangan dengan capaian kompetensi mata kuliah Biosistematika Tumbuhan. Capaian tersebut terdapat di dalam Rencana Pembelajaran Semester (RPS). Aspek tersebut juga dapat diartikan potensi sumber belajar antophyta sesuai dengan materi yang terdapat dalam suatu mata kuliah (V. P. Dewi et al., 2016). Aspek ini memperoleh presentase 87,50 dengan kriteria baik. Hal itu dapat diartikan bahwa semua capaian kompetensi atau materi yang terdapat di dalam RPS dapat didukung oleh potensi sumber belajar antophyta tersebut. Secar rinci kategori kesesuaian potensi sumber belajar antophyta dengan setiap capaian pembelajaran mata kuliah (CPMK) Biosistematika Tumbuhan tersaji pada tabel 6 berikut.

Salah satu CPMK yang berkaitan dengan pembelajaran saintifik adalah CPMK nomor 7. CPMK tersebut memperoleh kategori baik, yang berarti potensi sumber belajar antophyta dapat berpelang digunakan dengan baik untuk menunjang kegiatan pembelajaran saintifik pada mata kuliah Biosistemtika Tumbuhan. Hal yang dapat mendukung diperolehnya kategori tersebut karena potensi sumber belajar tersebut merupakan jenis sumber belajar by utilization, dengan fakta/konsep/prosedur yang ada belum terstruktur dan tersaji lengkap. Pendekatan saintifik kompatibel dengan penerapan pembelajaran di luar ruangan atau lingkungan sekitar sebagaimana hasil penelitian Rahyuni et al. (2018).

\section{Kelayakan Sumber Belajar Berdasarkan Aspek Kejelasan Sasaran}

Sasaran dalam yang dimaksud dalam analisis ini adalah sasaran pengamatan dan sasaran peruntukkan pembelajaran (Irawan \& Susilo, 2014), serta sasaran proses. Aspek kejelasan sasaran mendapatkan presentase tertinggi yaitu 87,50 dengan kriteria sangat baik, sehingga dapat dikatakan bahwa potensi sumber belajar antophyta memiliki kejelasan sasaran dalam ketiga hal tersebut. Sasaran pengamatan sangat jelas, yaitu karakteristik morfologis tumbuhan yang tergolong kelompok Anthophyta. Di lokasi pengamatan, tumbuhan-tumbuhan telah tersusun dengan teratur, sehingga dapat dibedakan antara satu kelompok dengan kelompok lainnya.. Sasaran peruntukan juga sangat jelas, yaitu digunakan untuk pembelajaran mata kuliah Biosistematika Tumbuhan dalam desain pembelajaran saintifik. Adapun sasaran proses sangat jelas, yaitu proses saintifik dengan 5 tahapnya, yaitu observing, questioning, experimenting, associating, dan communicating

\section{Kelayakan Sumber Belajar Berdasarkan Aspek Kejelasan Informasi Yang Diungkap}

Aspek kejelasan informasi yang diungkap memperoleh persentase 78,13\% dengan kategori baik. Hal tersebut menunjukkan bahwa potensi sumber belajar antophyta dapat secara baik memberikan informasi yang diperlukan dalam mata kuliah Biosistematika Tumbuhan. 
Beberapa informasi yang dapat diungkap melalui pemanfaatan potensi sumber belajar antophyta tersebut diantaranya tentang: a) karakter morfologis tumbuhan dimana hal itu berkaitan dengan struktur vegetatif seperti daun, batang, dan tunas serta struktur generatif seperti bunga, buah dan biji; b) jenis spesiesnya melalui proses identifikasi dan penerapan tata nama tumbuhan, dan; c) klasifikasi tumbuhan dengan mengelompokkan setiap jenis menggunakan kriteria tertentu. Menurut Handayanii et al. (2012) aspek tersebut juga berkaitan dengan produk yang diperoleh dari hasil eksplorasi dan analisisnya, dalam penelitian ini telah tersaji pada Tabel 2 dan Gambar 1.

\section{Kelayakan Sumber Belajar Berdasarkan Aspek Kejelasan Potensi Pedoman Eksplorasi}

Aspek ini berkaitan dengan kejelasan bentuk panduan eksplorasi dalam pemanfaatkan potensi sumber belajar antophyta dan peluang keterlaksanaannya. Aspek tersebut memperoleh presentase $83,33 \%$ dengan kategori baik. Perolehan tersebut didukung dengan beberapa hal: a) panduang ekspolasi dapat menggunakan instrumen yang digunakan dalam melakukan identifikasi dan klasifikasi antophyta sebelumnya yang berupa panduan observasi karakteristik tumbuhan dan buku pedoman identifikasi dan klasifikasi tumbuhan, b) lokasi eksplorasi memiliki letak strategis, di tepi jalan raya dan berada di wilayah kota yang memudahkan akses jalan menuju lokasi, c) dengan kemudahan akses jalan tersebut, waktu yang diperlukan menuju lokasi menjadi lebih singkat, sehingga dapat menghemat waktu. Poin b) dan c) sesuai dengan pendapat Situmorang (2016) yang menyatakan bahwa sebuah topik materi perlu diperhatikan keefektifannya dalam jangkauan dan waktu tempuhnya.

\section{Kelayakan Sumber Belajar Berdasarkan Aspek Kejelasan Potensi Perolehan Yang Diharapkan}

Aspek ini berkaitan perolehan aspek capaian kompetensi pembelajaran yang dapat diupayakan melalui pembelajaran Biosistematika Tumbuhan dengan memanfaatkan potensi sumber belajar antophyta. Capaian kompetensi pembelajaran terdiri dari aspek sikap, keterampilan, dan pengetahuan sesuai Standar Kompetensi Lulusan Pendidikan Tinggi (Peraturan Menteri Pendidikan Dan Kebudayaan Republik Indoneisa Nomor 3 Tahun 2020). Aspek tersebut mendapatkan presentase 79, 17\% dan memeproleh kategori baik, sehingga dapat dikatan potensi sumber belajar antophyta berpeluang dapat dengan baik diterapkan untuk memperoleh ketiga aspek capaian kompetensi tersebut dalam pembelajaran. Hal itu sesuai temuan Hatimah (dalam Dahlia; Ibrohim; Mahanal, 2016) yang menyatakan bahwa pembelajarn berbasis potensi lokal (lingkungan sekitar) mampu meningkatkan kemampuan kognitif, psikomotorik dan afektif peserta didik. Aspek sikap yang dapat diperoleh adalah sikap ilmiah. Sikap ilmiah dapat dijabarkan menjadi ingin tahu, perhatian terhadap data, berpikir kritis, sikap penemuan dan kreativitas, berpikir terbuka, tekun, dan peka terhadap lingkungan 
sekitar (N. L. Dewi et al., 2018). Adapun aspek pengetahuan yang dapat diperoleh berkaitan dengan materi utama Biosistematika Tumbuhan, yaitu deskripsi tumbuhan, identifikasi tumbuhan, tata nama tumbuhan, dan klasifikasi tumbuhan. Perpaduan antara pengetahuan dan sikap positif akan dapat mengembangkan keterampilah peserta didik sesuai dengan potensi lokal (Mumpuni, 2013). Aspek keterampilan yang dapat diperoleh keterampilan saintifik.

\section{SIMPULAN}

Berdasarkan hasil penelitian dan pembahasan yang telah dilakukan tentang identifikasi, klasifikasi, dan analisis tumbuhan antophyta di Kota Magelang sebagai sumber pembelajaran saintifik perkuliahan Biosistematika Tumbuhan dapat ditarik simpulan sebagai berikut. Pertama, terdapat 35 speseis tumbuhan antophyta yang memiliki karakteristik beraneka ragam. Semua spesies tersebut dapat diklasifikasikan secara hierarkis menjadi 32 genus, 25 famili, 16 ordo, dan 2 kelas. Kedua, Sumber belajar dengan memanfaatkan tumbuhan antophyta di Kota Magelang memperoleh persentase kelayakan sebesar 83,85\% dengan kategori baik, sehingga layak digunakan sebagai sumber belajar (by utilization) dalam kegiatan pembelajaran dengan pendekatan saintifik pada mata kuliah Biosistematika Tumbuhan. Rekomendasi yang dapat diberikan adalah perlu adanya penyusunan dan pengintegrasian potensi sumber belajar tersebut dalam suatu bentuk modul sehingga memudahkan mahasiswa dalam memanfaatkan potensi sumber belajar tersebut dalam pembelajaran saintifik.

\section{UCAPAN TERIMA KASIH}

Ucapan terima kasih kami sampaikan kepada civitas akademika Universitas Tidar, khsusnya di Program Studi Pendidikan Biologi, Dinas Lingungan Hidup Kota Magelang, dan seluruh pihak yang turut membantu dalam pelaksanaan dan penyusunan artikel penelitian ini, sehingga dapat terselesaikan dengan lancar.

\section{REFERENSI}

Aldridge, J. M., Fraser, B. J., Taylor, P. C., \& Chen, C. C. (2000). Constructivist learning environments in a crossnational study in Taiwan and Australia. International Journal of Science Education. https://doi.org/10.1080/095006900289994

Bhattacharyya, B. (2016). Botani Sistematik (2nd ed.). EGC.

Braby, M. F., \& Williams, M. R. (2016). Biosystematics and conservation biology: Critical scientific disciplines for the management of insect biological diversity. In Austral Entomology. https://doi.org/10.1111/aen.12158

Dahlia; Ibrohim; Mahanal, S. (2016). Pemanfaatan Potensi Hutan Wisata Baning Sebagai Sumber Belajar Interaksi Makhluk Hidup Dengan Lingkungan DI SMP. Seminar Nasional Pendidikan IPA, 873-886. http://pasca.um.ac.id/wpcontent/uploads/2017/02/Dahlia-873-886.pdf 
Dewi, N. L., Dantes, N., \& Sadia, I. W. (2018). Pengaruh Model Pembelajaran Inkuiri Terbimbing terhadap Hasil Belajar. Science and Physics Education Journal (SPEJ), 2(1), 1-10. https://doi.org/10.31539/spej.v2i1.333

Dewi, V. P., Hindun, I., \& Wahyuni, S. (2016). Studi Trikoma Daun Pada Famili Solanaceae Sebagai Sumber Belajar Biologi. JPBI (Jurnal Pendidikan Biologi Indonesia).

Gitakarma, M. S., \& Tjahyanti, L. P. A. S. (2012). Modifikasi Claroline dengan Metode Pembelajaran Computer-Supported Collaborative Learning (CSCL) Berbasis Konstruktivisme. Jurnal Nasional Pendidikan Teknik Informatika (JANAPATI), 1(1), 37. https://doi.org/10.23887/janapati.v1i1.9764

Gradstein, S. R., \& Stace, C. A. (1981). Plant Taxonomy and Biosystematics (Contemporary Biology). Taxon. https://doi.org/10.2307/1219972

Handayani, T., \& Amanah, N. (2018). Keanekaragaman Jenis Tumbuhan Strata Herba di Kawasan Gunung Tidar Kota Magelang sebagai Sumber Belajar Biologi Abstrak. 2, 8590.

Handayani, T., \& Findahati, M. M. (2018). Keanekaragaman Jenis Vegetasi Strata Semak di Kawasan Gunung Tidar Kota Magelang sebagai Sumber Belajar Biologi. Seminar Nasional Pendidikan FKIP UAD, 80-84.

Handayanii, T., Sugiarti, P., Api, G., Nglanggeran, P., Paku, T., \& Biologi, S. B. (2012). Keanekaragaman jenis tumbuhan paku di kawasan gunung api purba nglanggeran sebagai sumber belajar biologi sma kelas x materi keanekaragaman hayati. 683-692.

Ibrahim, N., \& Ishartiwi, I. (2017). Pengembangan Media Pembelajaran Mobile Learning Berbasis Android Mata Pelajaran Ipa Untuk Siswa Smp. Refleksi Edukatika: Jurnal Ilmiah Kependidikan, 8(1). https://doi.org/10.24176/re.v8i1.1792

Idu, M., Odara, T., \& Erhabor, J. O. (2011). Biosystematics Education in Nigerian Universities. 378-381.

Irawan, A., \& Susilo, M. J. (2014). Identifikasi potensi sumber belajar biologi sma kelas x di sekitar Goa Cerme Kabupaten Bantul untuk materi keanekaragaman jenis tumbuhan semak. Jupemasi-Pbio, 1(1), 113-116.

Jailani, M. sahran. (2017). Pengembangan Sumber Belajar Berbasis Karakter Peserta Didik (Ikhtiar optimalisasi Proses Pembelajaran Pendidi-kan Agama Islam (PAI)). Nadwa, 10(2), 175. https://doi.org/10.21580/nw.2016.10.2.1284

Machin, A. (2014). Implementasi pendekatan saintifik, penanaman karakter dan konservasi pada pembelajaran materi pertumbuhan. Jurnal Pendidikan IPA Indonesia, 3(1), 28-35. https://doi.org/10.15294/jpii.v3i1.2898

Mumpuni, K. E. (2013). Potensi Pendidikan Keunggulan Lokal Berbasis Karakter Dalam Pembelajaran Biologi Di Indonesia. Prosiding Seminar Nasional X Pendidikan Biologi FKIP UNS, 10(2), 1-7. http://www.jurnal.fkip.uns.ac.id/index.php/prosbio/article/download/3137/2177

Najmulmunir, N. (2010). Memanfaatkan Lingkungan Di Sekitar Sekolah Sebagai Pusat Sumber Belajar. Region.

Nurrohman, E., Abdulkadir, R., \& Sri, W. (2015). Keanekaragaman Makrofauna Tanah di Kawasan Perkebunan Coklat (Theobroma cacao L. ) sebagai Bioindikator Kesuburan Tanah dan Sumber Belajar Biologi. Jurnal Pendidikan Biologi Indonesia, 1(2), 197-208. http://202.52.52.22/index.php/jpbi/article/view/3331

Peraturan Daerah Kota Magelang Nomor 11 Tahun 2014. Tentang Brainding Kota Magelang Peraturan Menteri Pendidikan Dan Kebudayaan Republik Indoneisa Nomor 3 Tahun 2020. Tentang Standar Nasional Pendidikan Tinggi 
Primack, R. B. (2013). Locally adapted textbooks can help biodiversity. In BioScience. https://doi.org/10.1525/bio.2013.63.12.5

Probert, P. K. (2010). Conserving biosystematics. In Aquatic Conservation: Marine and Freshwater Ecosystems. https://doi.org/10.1002/aqc.1145

Rahyuni, R., Zamzaili, Z., \& Ruyani, A. (2018). Penerapan Pembelajaran Outdoor dengan Pendekatan Saintifik untuk Meningkatkan Hasil Belajar Siswa SMPN 6 Kota Bengkulu. PENDIPA Journal of Science Education, 2(3), 183-187. https://doi.org/10.33369/pendipa.2.3.183-187

Simpson, M. (2010). Plant systematics: Second edition. In Plant Systematics: Second Edition.

Singh, G. (2016). Plant systematics: An integrated approach: Third edition. In Plant Systematics: An Integrated Approach: Third edition. CRC Press.

Sitepu, B. P. (2017). Pengembangan Sumber Belajar. PT Rajagrafindo Persada.

Situmorang, R. (2016). Analisis Potensi Lokal Untuk Mengembangkan Bahan Ajar Biologi Di Sma Negeri 2 Wonosari. Jurnal Pendidikan Sains Universitas Muhammadiyah Semarang, 4(1), 51-57. https://doi.org/10.26714/jps.4.1.2016.51-57

Suhardi. (2012). Pengembangan Sumber Belajar. Universitas Negeri Yogyakarta.

Sujarwanta, A. (2012). Mengondisikan Pembelajaran IPA dengan Pendekatan Saintifik. Jurnal Nuansa Kependidikan, 16(1).

Sundawan, M, D. (2016). Perbedaan Model Pembelajaran Konstruktivisme Dan Model Pembelajaran Langsung. Jurnal Logika, XVI(1), 1-11.

Suratsih, Henuhili, V., Rahayu, T., \& Nuria W, R. K. (2009). Penyusunan Sumber Belajar Genetika Berbasis Potensi Lokal Dalam Bentuk Modul Pembelajaran. Seminar Nasional Biologi, Lingkungan Dan Pembelajaranya, 724-741.

Sutrisno, H. (2016). Peran Ilmu Dasar Biosistematika Pada Era Bioteknologi. Seminar Nasional Biotik 2016, X, 1-21.

Tjitrosoepomo, G. (2013). Taksonomi Tumbuhan (Spermatophyta). Gajah Mada University Press.

Valentine, D. H., \& Love, A. (1958). Taxonomic and biosystematic categories (Issue October).

Vane-Wright, R. I. (2013). Taxonomy, Methods of. Encyclopedia of Biodiversity: Second Edition, 7, 97-111. https://doi.org/10.1016/B978-0-12-384719-5.00141-6

Wibowo, E. P. (2016). Kompetensi Guru Dalam Pemanfaatan Sumber Belajar By Utilization Di Sdn Caturtunggal 6. E-Jurnal Prodi Teknologi Pendidikan, 5, 10-20.

Yuliati, Y. (2017). Miskonsepsi Siswa Pada Pembelajaran Ipa Serta Remediasinya. Journal Bio Educatio, 2(2), 50-58.

Yusuf, O. (2018). Kamera Pintar Google Lens Disebar ke Semua Android. https://tekno.kompas.com/read/2018/03/07/12375637/kamera-pintar-google-lensdisebar-ke-semua-android

Zubaidah, S. (2014). Pemberdayaan Keterampilan Penemuan dalam Scientific Approach Melalui Pembelajaran Berbasis Remap Coople. Seminar Nasional XI Pendidikan Biologi FKIP UNS Biologi, Sains, Lingkungan, Dan Pembelajarannya, 1000-1011.

Zulkarnain. (2009). Kearifan Lokal dalam Pemanfaatan dan Pelestarian Sumberdaya Pesisir (Studi Kasus di Desa Panglima Raja Kecamatan Concong Kabupaten Indragiri Hilir Propinsi Riau). Jurnal Berkala Perikanan Terubuk. 